\title{
Jaka ontologia języka?
}

\section{Andrzej Biłat}

WSPA w Lublinie

Każda niepołączona wypowiedź oznacza albo substancję, albo ilość, albo jakość, albo stosunek, albo miejsce, albo czas, albo położenie, albo stan, albo działanie, albo doznawanie.

Arystoteles, Kategorie ${ }^{1}$

Rozpoczynamy teraz naukę o własnościach wszystkich w ogóle przedmiotów, zwaną ontologią. [...] Łatwo można zrozumieć, że będzie ona zawierać wszystkie podstawowe pojęcia i podstawowe sądy naszego poznania a priori.

Immanuel Kant, Wykłady z metafizyki²

Poszukiwania najprostszego, najjaśniejszego, ogólnego wzoru kanonicznej notacji nie należy odróżniać od poszukiwania ostatecznych kategorii, od szkicowania najogólniejszych cech rzeczywistości.

Willard Van Orman Quine, Słowo i przedmiot ${ }^{3}$

\section{Wstęp}

Ontologia jest studium podstawowych kategorii bytów i relacji między nimi. ${ }^{4}$ Jej celem jest porządkujący opis ogółu wszelkich bytów, dostarczający odpowiedzi na pytanie Co istnieje?5

Ontologia języka jest ontologią uprawianą w kontekście filozofii języka. Jej podstawowym zadaniem jest rekonstrukcja systemu kategorii i relacji ontologicznych wyznaczonych przez uniwersalne wyrażenia języka naturalnego.

1 Arystoteles (1990: 34). Zwrot „niepołączona wypowiedź” należy w tym kontekście rozumieć jako „wyraz prosty”.

2 Kant (1997: 140).

3 Quine (1999: 187).

4 Podobne określenia występują w pracach: Smith (2003: 155) i Gracia (1999: 147).

5 Por. Quine (1969: 9). 
Termin „ontologia języka” (w skrócie: OJ) nie jest dość często stosowany we współczesnej literaturze filozoficznej. ${ }^{6}$ Jest natomiast terminem wygodnym i z tego względu wart jest — jak się wydaje — upowszechnienia.

OJ nie jest też, jak dotąd, wyraźnie wyodrębnionym działem filozofii języka. Jest zespołem specyficznych zagadnień, istotnie wzbogacających pragmatyczną problematykę (okazjonalności, postaw zdaniowych, presupozycji, implikatury, aktów mowy itd.), typową dla (analitycznej) filozofii języka ostatnich dziesięcioleci. Problematyka OJ obejmuje zasadniczo kwestie związane z kategorią schematu pojęciowego leżącego u podstaw języka naturalnego.

OJ dostarcza intuicyjnej ontologii dodatkowych metod, w szczególności kryterium oceny rozstrzygnięć ontologicznych. Zgodnie z tym kryterium dobra odpowiedź na pytanie Co istnieje? jest odpowiedzią uzasadnioną i/lub użyteczną w dobrej filozofii języka.

OJ nie powinna być utożsamiana z całą ontologią analityczną. Przedstawiciele filozofii analitycznej zgadzają się wprawdzie z tezą o językowym uwarunkowaniu ontologii, na ogół jednak nie utożsamiają filozofii z filozofią języka (znanym wyjątkiem była „oksfordzka” szkoła filozofii lingwistycznej). Tezy, iż wszelkie rozważania z zakresu analitycznej ontologii są częścią ontologii języka, trudno byłoby dziś skutecznie bronić (uwzględniając choćby fakt analitycznej ontologii nauki).

Poszczególne wersje OJ są mniej lub bardziej sformalizowane (zależnie od stopnia teoretycznego zaawansowania i przyjętej koncepcji roli logiki w analizie językowej). Przykładem niesformalizowanej OJ jest metafizyka opisowa Petera Strawsona7 ${ }^{7}$ częściowo sformalizowanej - teoria prawdy dla języka naturalnego Donalda Davidsona $^{8}$, a w pełni sformalizowanej — ontologia i mereologia Stanisława Leśniewskiego 9 .

Celem tego rozdziału jest objaśnienie istoty funkcjonujących współcześnie paradygmatów w OJ (w pierwszej części), usystematyzowanie podejść badawczych OJ, stosowanych w ramach paradygmatu semantycznego (ogólnie w drugiej części), ze szczególnym uwzględnieniem podejścia logiczno-kwantyfikatorowego (zasadniczo w części trzeciej). ${ }^{10}$

6 W ostatnich latach zwrot ten pojawił się w tytule książki Fox (2000). Książka ta zawiera pewien sformalizowany system teorii własności. Rozważania metaontologiczne są w niej ograniczone do kilku luźnych uwag i nie zawierają żadnych definicji terminów „ontologia”, „ontologia języka” ani też „ontologia języka naturalnego” (ontology of natural language). Zwroty te są natomiast często używane $\mathrm{w}$ badaniach z zakresu computer science.

7 Zob. np. Strawson (1980), Strawson (1994).

8 Zob. np. Davidson (1995).

9 Wprowadzenie w formalne zagadnienia ontologii Leśniewskiego zawiera m.in. podręcznik Borkowskiego (1991: 187-199), a w formalne zagadnienia mereologii — pierwszy rozdział monografii Pietruszczaka (2000: 7-60). Według Borkowskiego, „ontologia Leśniewskiego lepiej odpowiada językowi naturalnemu niż rachunek predykatów. Słówko jest, będące jej terminem pierwotnym, występuje we wszystkich bardziej rozpowszechnionych językach naturalnych. W językach tych występują nazwy ogólne, jednostkowe i puste; w ontologii Leśniewskiego za zmienne nazwowe można podstawiać nazwy ogólne, jednostkowe i puste, podczas, gdy w rachunku predykatów za zmienne nazwowe można podstawiać tylko nazwy jednostkowe” (tamże, s. 199). Do klasy sformalizowanych ontologii języka naturalnego zaliczane są też niektóre systemy ontologii informatycznej, np. DOLCE.

10 OJ, w znaczeniu przyjętym w tym rozdziale, należy odróżnić od ontologii przedmiotów językowych (znaków, ich semantycznych korelatów, ekstensji, intensji, czynności językowych itd.). Tego typu roz- 


\section{Paradygmaty ontologii języka}

Współczesna ontologia, w szczególności OJ, jest najczęściej uprawiana w ramach jednego z czterech paradygmatów: metafizycznego, logicznego, informatycznego lub semantycznego. Ponieważ ostatni z nich jest najbardziej związany z typowymi zagadnieniami filozofii języka, może być zdefiniowany jako OJ w ścisłym, węższym znaczeniu.

Paradygmat metafizyczny. W ramach tego paradygmatu ontologia jest teoretyczną podstawą metafizyki, w jednym z dwóch znaczeń tego słowa, „leibnizjańskim” lub „kantowskim”.

W wariancie „leibnizjańskim” ontologia jest teorią bytów nie tylko realnych, ale także czysto możliwych, ewentualnie też idealnych i fikcyjnych (chętnie rezygnuje się tu z terminu „byt” na rzecz terminu „przedmiot”); z kolei metafizyka dotyczy bytów wyłącznie realnych. W tym ujęciu uniwersum metafizyczne jest fragmentem uniwersum ontologicznego.

W wariancie „kantowskim” ontologia jest czysto analityczną częścią ogólnej teorii bytów, a więc częścią, której celem jest objaśnienie i systematyzacja podstawowych pojęć metafizyki. Metafizyka jest tutaj pewnym nieanalitycznym (syntetycznym) rozwinięciem ontologii.

Powyższa koncepcja ontologii przyjmuje we współczesnej filozofii języka postać analiz podstawowych kategorii języka naturalnego, prowadzonych w kontekście rozważań metafizycznych o charakterze eksplanatywnym („leibnizjańskim”) bądź deskryptywnym („kantowskim”).

Przykładem eksplanatywnej wersji OJ są wyjaśnienia Davida Lewisa i Saula Kripkego zjawisk językowych związanych z modalnością (w szczególności powszechnego użycia zwrotów modalnych oraz wyrażeń oznaczających „sztywno” i „niesztywno”) w kategoriach światów możliwych, a także analizy kategorii zdarzeń i czynności, związane z logiczną teorią przysłówków Donalda Davidsona. ${ }^{11} \mathrm{Z}$ kolei przykładem deskryptywnej wersji OJ jest koncepcja Strawsona metafizyki opisowej jako analizy językowej zmierzającej do uwyraźnienia podstawowej struktury naszego myślenia. ${ }^{12}$

Dodajmy, że z omawianym paradygmatem często wiąże się idea, że ontologia jest rodzajem unaukowionej metafizyki. ${ }^{13}$ Istnienie tych dwóch typów refleksji o naturze bytu, spekulatywno-metafizycznej i naukowo-ontologicznej, jest widoczne już u Platona oraz — zwłaszcza - u Arystotelesa. Metafizyka Stagiryty jest dziełem typowo metafizycznym, a Kategorie - ontologicznym. ${ }^{14}$

ważania, również opatrywane nazwą „ontologia języka”, są niekiedy inspirowane klasycznymi koncepcjami filozoficznymi; zob. np.: Smith (1987), Sarbo, Farkas (2001).

11 Zob. np. artykuły Lewisa, Kripkego i Davidsona, zamieszczone w: Szubka (red.), (1995).

12 Por.: Strawson (1960: 263), Szubka (red.), (1995: 65-66), Strawson (1980).

13 W przeciwieństwie do starożytnego wyrazu „metafizyka” (o wiele starszego od wyrazu „ontologia”, który pojawił się dopiero w XVII w.) termin ten od początku swojej filozoficznej kariery chętnie był stosowany w celu podkreślenia związku ontologii z nauką. Świadczy o tym tytuł dzieła Johanna Christiana Wolffa, dzięki któremu termin ten wszedł na stałe do słowników filozoficznych: Philosophia Prima sive Ontologia methodo scientifica pertractata quo omnis cognitionis humanae principia continentur (pierwsze wydanie w 1730 r., potem wznawiane co kilka lat).

14 Pomimo tych różnic w treści terminów „ontologia” i „metafizyka”, nierzadko używa się ich zamiennie. Przykładami rozważań, które zasługują raczej na miano „metafizycznych”, są współczesne dyskusje fi- 
Paradygmat logiczny. Idea ontologii jako „unaukowionej metafizyki” przyjmuje niekiedy postać tezy o identyczności ontologii z przedmiotowo zinterpretowaną logiką formalną. Ujęcie to ma swoje źródło w koncepcji logiki Gottloba Fregego i Bertranda Russella, według których logika wyższych rzędów jest w istocie najogólniejszą teorią rzeczywistości. Za nimi wielu autorów, w tym Tadeusz Kotarbiński, Tadeusz Czeżowski, a zwłaszcza Józef Bocheński oraz — w ostatnich latach — Nino Cocchiarella, rozwijali podobne stanowisko. Oto kilka reprezentatywnych wypowiedzi.

[...] Jeżeli Arystotelesowską definicję teorii naczelnej [...] interpretować w duchu „ogólnej teorii przedmiotów”, wtedy zarówno co do brzmienia, jak co do sensu można ją zastosować do rachunku nazw w ujęciu Leśniewskiego. [Kotarbiński, 1961: 253] Prawa logiki formalnej należą do dziedziny ogólnej teorii przedmiotów. [Kotarbiński, 1961: 534].

Urzeczywistnia ona [metafizyka aksjomatyczna — przyp. A. B.] w swoisty sposób ideał metafizyki dedukcyjnej, przyświecający Kartezjuszowi i Spinozie, ale zarazem ma rysy wspólne zarówno z koncepcją Platońską, jak i Arystotelesowską metafizyką. Z Platonem ma to wspólne, że jest logiką i metafizyką zarazem; jak Platońska dialektyka była teorią pojęć i teorią idei, tak i nowoczesna logika zdaje sobie sprawę z tego, że może być interpretowana bądź jako nauka o związkach międzyzdaniowych i międzynazwowych, czyli logika [właściwa — przyp. A. B.], bądź jako teoria podająca najogólniejsze własności przedmiotów, co Arystoteles miał za cel w swej pierwszej filozofii. Lecz obraz świata, który daje logika nowoczesna, jest różny od obrazu Platońsko-Arystotelesowskiego tak właśnie, jak różna jest nowoczesna logika od tamtej. [Czeżowski, 1998: 68].

Ontologia jest po prostu najbardziej abstrakcyjną teorią przedmiotu w ogóle [...], jest niczym innym jak logiką formalną. Lub ściślej, ontologia, tak jak się ją zazwyczaj uprawia, są to tylko prolegomena do aksjomatycznego traktowania tego samego przedmiotu w logice. [Bocheński, 1993: XXVII-XXVIII].

Ontologia formalna jest rezultatem połączenia intuicyjnych, nieformalnych metod klasycznej ontologii z formalnymi, matematycznymi metodami współczesnej logiki symbolicznej [...], jest systematycznym, formalnym, aksjomatycznym rozwinięciem logiki dowolnych form i sposobów bytowania [...]. Logika może być odróżniona od formalnej ontologii, lecz wyłącznie w sensie logiki jako niezinterpretowanego rachunku. [Cocchiarella, 1991]. Formalna ontologia łączy logiczne kategorie - w szczególności kategorie związane z predykacją — z kategoriami ontologicznymi. Celem formalnej ontologii jest konstrukcja lingua philosophica lub characteristica universalis, rozumiana — za pomocą pojęć ars combinatoria i calculus ratiocinator - jako część formalnej teorii predykacji. [Cocchiarella, 2007: 23].

lozofów analitycznych w ramach tzw. ontologii światów możliwych na temat egzystencjalnego statusu świata aktualnego (czy świat aktualny jest wyróżniony wyłącznie na tej podstawie, że jesteśmy jego mieszkańcami?) czy też dyskusje wokół niektórych szczegółowych zagadnień z zakresu tzw. ontologii umysłu. Por. Gracia, tamże. 
Wbrew widocznej w tych wypowiedziach tendencji do utożsamienia zakresów pojęć „system ontologii formalnej” i „zinterpretowany rachunek logiczny”, za wyraźnym odróżnianiem obu pojęć przemawiają następujące względy.

Podstawowe funkcje logiki i ontologii nie są tożsame. Zgodnie z tradycyjnym pojęciem tej pierwszej jako narzędzia poznania, głównym zadaniem logiki nie jest opis najogólniejszych cech rzeczywistości, lecz dostarczenie - możliwie neutralnego filozoficznie - narzędzia analizy poprawności wnioskowań oraz formalizacji teorii. Zatem logika i ontologia są to dwie odmiennie motywowane formy aktywności poznawczej.

Różne motywy konstrukcji systemów logiki i systemów ontologii wyznaczają różne struktury pojęciowe. Terminami pierwotnymi systemów logicznych są wyłącznie stałe logiczne (w standardowej logice są to: podstawowe spójniki logiczne, kwantyfikatory właściwe oraz predykat identyczności). Z kolei nawet w najbliższych logice teoriach o charakterze ontologicznym, takich jak teoria mnogości z indywiduami, oprócz tych stałych występują zwykle jeszcze specyficzne stałe pozalogiczne (np. „należy” i ,jest zbiorem”). Najczęściej przyjmuje się, że predykaty te nie są definiowalne w systemach czysto logicznych.

Ponadto nawet gdybyśmy ograniczyli ontologię do teorii wyrażalnej w języku czystej logiki (tj. języku logiki, pozbawionym stałych pozalogicznych), to i tak musielibyśmy przyjąć, że specyficzne tezy ontologii, jako formuły nietautologiczne, nie są tezami logiki (prostym przykładem jest formuła $\exists x \exists y(x \neq y)$ głosząca, że istnieją przynajmniej dwa przedmioty). Zatem nawet najbardziej „zlogicyzowany” system ontologii nie może być utożsamiony z przedmiotowo zinterpretowanym systemem logicznym, pojętym jako układ tautologii.

Korekta rozważanej idei ontologii, uwzględniająca powyższe zastrzeżenia, prowadzi do koncepcji „ontologii logicznej” jako bezpośredniego rozszerzenia przedmiotowo zinterpretowanej logiki formalnej, w szczególności - rozszerzenia w postaci logicznej teorii indywiduów, klas i relacji.

Zatem w ramach omawianego paradygmatu OJ należy rozumieć jako logiczną ontologię języka, tj. ontologię logiczną budowaną w kontekście filozofii języka. Przykładami pojęć rozważanych w tak rozumianej OJ są pojęcia bytu, związane z rozmaitymi znaczeniami terminów „jest” i „istnieje”, a także kategoria sytuacji opisanej zdaniem. ${ }^{15}$

Paradygmat informatyczny. Inżynieria ontologiczna jest młodym i niezwykle szybko rozwijającym się działem szeroko pojętej informatyki, związanym z projektowaniem i implementacją systemów pojęciowych reprezentujących podstawową strukturę relacyjną danej dziedziny przedmiotowej. Takie systemy zwykło określać się obecnie w informatyce „ontologiami”. ${ }^{16}$ Znaczenie konstrukcji tych systemów w naukach technicznych objaśnia następujący cytat.

15 Klasycznym przykładem systemu logicznej OJ jest ontologia Leśniewskiego. Współczesnym przykładem tak rozumianej OJ są analizy logiczno-lingwistyczne Jerzego Perzanowskiego. Zob. np. Perzanowski (1988). Warto przy okazji wspomnieć, że przynajmniej dwa wygodne terminy, używane w kontekście OJ, mianowicie „filozofia logiczna” i „ontologika”, zostały upowszechnione w języku filozoficznym przez Perzanowskiego. Przykład systemu logicznej ontologii sytuacji, uwzględniającej sposób funkcjonowania pojęcia sytuacji w języku naturalnym, zawiera artykuł Biłata (2009).

16 Termin „ontologia” jest dziś najczęściej używany w piśmiennictwie naukowym właśnie w tym znaczeniu. W lutym 2008 r. liczba wyników zapytania dla wyrazu „ontology” w wyszukiwarce Google 
Analiza ontologiczna ujawnia strukturę wiedzy. [...] Pierwszym krokiem na drodze do skonstruowania efektywnego systemu reprezentacji wiedzy [...] jest wykonanie efektywnej analizy ontologicznej danej dziedziny. Kiepskie analizy prowadzą do niespójnych baz wiedzy [...]. Objaśnienie terminologii umożliwia ontologii funkcjonowanie dla spójnych i jednolitych mechanizmów inferencyjnych [...]. Ontologie umożliwiają dzielenie się wiedzą (knowledge sharing) [...]. Współdzielone ontologie (shared ontologies) mogą zatem stanowić podstawę dla szczegółowych języków reprezentacji wiedzy. ${ }^{17}$

Jak widać, filozoficzne i informatyczne systemy ontologii są podobne pod względem przypisywanych im funkcji poznawczych, różnice polegają głównie na sposobie ich praktycznego wykorzystania oraz na różnicy zakresów opisywanych dziedzin. Różnice te maleją zresztą w przypadkach podstawowych systemów ontologii informatycznej (foundation ontology, top-level ontology, upper ontology), służących do opisu dowolnych dziedzin przedmiotowych. ${ }^{18}$ Najogólniejsze fragmenty zaksjomatyzowanych wersji niektórych spośród tych systemów (np. BFO) mogłyby być zaliczone równie dobrze do filozoficznej ontologii formalnej. Różnią je głównie konteksty ich konstrukcji i zastosowań: z jednej strony praktyczno-techniczne, z drugiej teoretyczno-poznawcze.

W konstrukcjach podstawowych systemów ontologii ważną rolę odgrywają analizy o charakterze lingwistycznym (dotyczy to w szczególności systemów DOLCE i WordNet). Ponadto istnieje wiele niepodstawowych systemów ontologii, dotyczących specyficznych (praktycznych) zagadnień języka naturalnego. Ogół tych analiz i zagadnień wyznacza informatyczny paradygmat OJ.

Paradygmat semantyczny. Jak wiadomo, w ontologii, a zwłaszcza w OJ, niezwykle ważną rolę pełni semantyka. Ścisły związek rozważań ontologicznych i semantycznych widoczny jest już choćby w treści naszego motta. Arystoteles w kontekście typowo ontologicznych rozważań pisze najczęściej o bytach oznaczanych przez wyrażenia. $\mathrm{Z}$ kolei Kant traktuje ontologię jako naukę składającą się z podstawowych sądów a priori. Kant miał tu zresztą na myśli sądy analityczne a priori (a więc sądy eksplikujące jedynie znaczenia terminów), o czym świadczy następujący cytat:

Rozważania takie [dotyczące przedstawionej wcześniej tablicy kategorii — przyp. A. B.] są bardzo pożyteczne. Jeśli poza tym wyliczymy wszystkie predicabilia, które możemy w sposób zupełny zaczerpnąć z każdej dobrej ontologii (np. Baumgartena), i podporządkujemy je według klas kategoriom [...], to

wyniosła około 11600 000, z których zdecydowana większość była związana z kontekstem informatycznym, w lipcu 2009 r. liczba ta wynosiła już prawie 21000000.

17 Chandrasekaran et al. (1999: 21), cyt. za: Garbacz (2009). Choć inżynieria ontologiczna rozwija się dopiero od kilkunastu lat, liczba prac jej dotyczących jest ogromna. Porównanie ontologii inżynieryjnych z ontologią filozoficzną można znaleźć w: Trypuz, Garbacz (2007).

18 Do podstawowych systemów ontologii zalicza się obecnie przynajmniej kilka systemów, m.in. Cyc, BFO (Basic Formal Ontology, stworzony przez Barry’ego Smitha i jego współpracowników), DOLCE (Descriptive Ontology for Linguistic and Cognitive Engineering, skonstruowany przez Nicola Guarino i jego współpracowników), WordNet (zbudowany w oparciu o zasady psycholingwistyki, niezaksjomatyzowany, szeroko stosowany w badaniach nad procesami przetwarzania języka naturalnego) i SUMO (Suggested Upper Merged Ontology). 
w ten sposób powstanie czysto analityczna część metafizyki, która [...] mogłaby poprzedzać część drugą (syntetyczną), a przez swą określoność i zupełność byłaby nie tylko pożyteczna, lecz dzięki systematyczności miałaby w sobie jeszcze nadto pewne piękno. ${ }^{19}$

I wreszcie Quine postulował użycie, jako głównej metody uprawiania ontologii, semantycznej w gruncie rzeczy techniki parafrazy zdań języka, w którym zobowiązania ontologiczne są nieujawnione, na język standardowej logiki kwantyfikatorów (język „kanonicznej notacji”), w którym te zobowiązania są widoczne.

Pomimo bliskiego związku ontologii z semantyką, istnieje między nimi dość istotna różnica: głównym przedmiotem ontologii, w przeciwieństwie do semantyki, nie są znaki, lecz byty, do których te znaki się odnoszą. Semantyka nie jest tożsama $\mathrm{z}$ ontologią, choć jest istotnym — i zapewne najważniejszym w OJ — składnikiem metody ontologicznej.

Paradygmat semantyczny, jako najbliżej związany z językoznawstwem i typową problematyką filozofii języka, zostanie dokładniej omówiony w następnych częściach rozdziału.

\section{Podejścia badawcze w ramach paradygmatu semantycznego}

Podstawą konstrukcji dobrego systemu ontologii jest naturalne kryterium odróżniania kategorii ontologicznych. Stosowane dotychczas w filozofii analitycznej kryteria można podzielić z jednej strony na lingwistyczne i logiczne, a z drugiej — na składniowe i kwantyfikatorowe. Kryteria składniowe polegają na przypisaniu (wszystkim lub tylko niektórym) kategoriom składniowym lub leksykalnym języka (naturalnego bądź języka logiki) odpowiednich kategorii ontologicznych. Natomiast według kryterium kwantyfikatorowego, kategorie ontologiczne są identyczne bądź z zakresami kwantyfikatorów wyrażanych przez pewne zaimki nieokreślone, bądź z zakresami operatorów pytajnych wyrażanych przez niektóre zaimki pytajne.

Krzyżując oba rozróżnienia, otrzymujemy cztery podejścia badawcze: 1) lingwistyczno-składniowe, 2) lingwistyczno-kwantyfikatorowe, 3) logiczno-składniowe oraz 4) logiczno-kwantyfikatorowe. Głównym celem dalszych rozważań tej części jest egzemplifikacja każdego z tych podejść.

Podejście lingwistyczno-składniowe. Przykładem użycia tego typu kryterium jest gramatyczna interpretacja (pochodząca od F. A. Trendelenburga) teorii kategorii Arystotelesa, polegająca na przyporządkowaniu poszczególnym kategoriom następujących części mowy: 1) SUBSTANCJA - rzeczownik, 2) ILOŚĆ - liczebnik, 3) JAKOŚĆ - przymiotnik, 4) STOSUNEK - przymiotnik w stopniu wyższym, 5) MIEJSCE - przysłówek miejsca, 6) CZAS - przysłówek czasu, 7) POŁOŻENIE - czasownik nieprzechodni, 8) STAN/POSIADANIE - czasownik przechodni, 9) DZIAŁANIE - czasownik w stronie czynnej, 10) DOZNAWANIE — czasownik w stronie biernej. 20

19 Kant (1993: 116).

20 Trendelenburg (1846). 
Zestaw ten został na przełomie XIX i XX wieku zredukowany przez Wilhelma Wundta do czterech: 1) SUBSTANCJA (RZECZ) - rzeczownik, 2) TRWAŁA CECHA (PRZYMIOT) - przymiotnik i liczebnik, 3) ZMIENNY STAN (RZECZY) - czasownik, 4) STOSUNEK - przysłówki, przyimki, końcówki przypadków, formy czasownikowe. ${ }^{21}$

Klasycznym zarzutem stawianym wobec tego rodzaju aprioryczno-filozoficznego podejścia w analizie kategorii języka naturalnego jest zarzut arbitralności. ${ }^{22}$ Możliwości jego uniknięcia mogłyby dostarczyć empiryczne badania zmierzające do określenia uniwersalnych i definicyjnie pierwotnych znaczeń językowych występujących we wszystkich lub przynajmniej w większości języków etnicznych.

Takie badania zostały faktycznie podjęte w ramach językoznawczego programu badawczego Anny Wierzbickiej. Zgodnie z dotychczasowymi ustaleniami badaczy realizujących ten program, do takich uniwersalnych znaczeń należą między innymi pojęcia: NIE, TEN SAM-INNY, JEDEN, DWA, WSZYSTKO, RODZAJ, CZĘŚĆ, TAKI-JAK, KIEDY, PRZED-PO, GDZIE, POD-NAD, KTOŚ, COŚ, TEN, MYŚLEĆ, WIEDZIEĆ, MÓWIĆ, ROBIĆ, ZDARZAĆ SIĘ, MÓC, Z POWODU. ${ }^{23}$

Ten podstawowy fragment „listy Wierzbickiej” dostarcza interesujących wskazówek w konstrukcji systemów ontologii formalnej, związanych z OJ. Po pierwsze, potwierdza naturalność i uniwersalność zwykłych stałych logicznych: negacji, identyczności i podstawowych kwantyfikatorów. Po drugie, potwierdza zwykłą intuicję, że dla użytkowników języka naturalnego wzorcowymi przykładami indywiduów są osoby („ktoś”, „ten ktos””, „ktoś taki, jak” itd.) i zwykłe rzeczy („coś”, „to coś” itd.). Po trzecie, sugeruje uniwersalny charakter postulatu istnienia bytów intencjonalnych, w szczególności propozycjonalnych (jeżeli ktoś myśli o czymś, to istnieje przedmiot tej myśli; jeśli ktoś wie, że jest tak a tak, to istnieje coś, co jest przedmiotem tej wiedzy). I wreszcie, wskazuje na pewne naturalne kierunki badań ontologicznych związanych z pojęciami: rodzaju, całości i części, relacji podobieństwa („bycia takim jak"), czynności, zdarzenia, myśli, wypowiedzi czy też relacji przyczynowoskutkowej.

Podejście lingwistyczno-kwantyfikatorowe. Użycie tego kryterium polega zasadniczo na rekonstrukcji listy kategorii ontologicznych, która odpowiada pewnym podstawowym w języku naturalnym zaimkom nieokreślonym (wersja ściśle kwantyfikatorowa) lub zaimkom pytajnym (wersja erotetyczna).

Przykładem użycia wersji ściśle kwantyfikatorowej jest analiza Jaakko Hintikki podstawowych zaimków języka naturalnego: „kto”, „co”, „kiedy”, „gdzie”, „dlaczego”, „jak”, „ile” i „jaki”, jako kwantyfikatorów tego języka, a następnie utożsamienie ich zakresów z kategoriami: OSOBA, RZECZ, CZAS, MIEJSCE, RACJA, SPOSÓB, ILOŚĆ, JAKOŚĆ. 24

21 Zob. Wojtysiak (2002: 104-105).

22 „Oto owych dziesięć kategorii Arystotelesa, z których robi się taką tajemnicę, jakkolwiek, prawdę powiedziawszy, niewielki z nich pożytek [...] uważa się te kategorie za rzecz ustanowioną przez rozum i przez prawdę, a tymczasem są one całkowicie dowolne [..] ci bowiem [inni ludzie — przyp. A. B.] mogą z równą słusznością, każdy wedle swego sposobu filozofowania, uporządkować inaczej przedmioty swoich myśli." (Arnould, Nicole, 1958: 61).

23 Zob. Wierzbicka (2006).

24 Hintikka (1983). 
Klasycznym przykładem wersji erotetycznej jest powiązanie przez Tadeusza Kotarbińskiego Arystotelesowskich kategorii z odpowiednimi zaimkami: SUBSTANCJA — „CO?”, 2) ILOŚĆ — ,jak liczny?” lub „jaki duży?” 3) JAKOŚĆ — ,jaki?”, 4) STOSUNEK — „Względem czego?”, 5) MIEJSCE — „gdzie?”, 6) CZAS — „kiedy?”, 7) POŁOŻENIE — „W jakim położeniu?”, 8) STAN/POSIADANIE — „jak się ma?”, 9) DZIAŁANIE — „co czyni?”, 10) DOZNAWANIE — „czego doznaje?”.25

Podejście logiczno-składniowe. Podejście to polega na przypisaniu kategorii ontologicznych kategoriom syntaktycznym (wszystkim lub tylko niektórym) danego systemu form logicznych. Wariantów tego podejścia jest wiele, a ich wybór zależy od koncepcji formy logicznej oraz metody ewentualnej redukcji kategorii (redukcja taka ma miejsce przy założeniu, że nie wszystkim kategoriom syntaktycznym odpowiadają kategorie ontologiczne).

Jeśli na przykład potraktujemy logikę fregowską (dokładniej — prawdziwościową logikę predykatów, pochodzącą od Gottloba Fregego) oraz logikę niefregowską (logikę predykatów z nieprawdziwościowym spójnikiem identyczności, skonstruowaną przez Romana Suszkę) jako dwa alternatywne systemy form logicznych, to w ramach omawianego podejścia będziemy dysponować przynajmniej dwoma alternatywnymi systemami OJ. Zgodnie z systemem fregowskim są dokładnie dwie kategorie ontologiczne: przedmiotów (obejmuje semantyczne korelaty nazw jednostkowych oraz obie wartości logiczne) i funkcji (semantycznych korelatów funktorów). Zgodnie z systemem niefregowskim są dokładnie trzy takie kategorie: przedmiotów (semantycznych korelatów nazw jednostkowych), sytuacji (semantycznych korelatów zdań) i funkcji (semantyczne korelaty funktorów). ${ }^{26}$

Przykładem logiczno-składniowego systemu kategorii jest teoria typów pochodząca od Bertranda Russella (i wciąż odgrywająca we współczesnej OJ, zwłaszcza związanej z paradygmatem informatycznym, dość istotną rolę). Podejście to jest też popularne — głównie dzięki pracom Suszki — w polskiej literaturze logiczno-filozoficznej.

Podejście logiczno-kwantyfikatorowe. Podstawą tego podejścia jest koncepcja ontologicznych zobowiązań, pochodząca od Quine’a. Według Quine’a występowanie stałych nazwowych w języku nie jest logicznie istotne (ich użycie można zredukować do użycia odpowiednich predykatów). Kanoniczną postacią odniesienia semantycznego jest odniesienie zmiennej nazwowej do przedmiotu będącego jej wartością; Quine powiada krótko: „być, to znaczy być wartością zmiennej” (Quine, 2000: 44). Podkreśla też, że podstawowym, logicznym środkiem wyrażenia faktu istnienia jest kwantyfikator egzystencjalny, wiążący zmienną nazwową w danej formule logicznej. Przyjmuje, że standardowy system formuł logicznych — logiki kwantyfikatorów pierwszego rzędu z identycznością — jest językiem „notacji kanonicznej”, czyli językiem form logicznych, w którym każde sensowne zdanie języka naturalnego przyjmuje semantycznie przejrzystą postać, ujawniającą w szczególności wszystkie jego ukryte zobowiązania ontologiczne.

25 Jednocześnie Kotarbiński podkreśla pierwotnie semantyczny charakter kategorii Arystotelesa, zob. Kotarbiński (1961: 67-68).

26 Według Mieczysława Omyły „Ontologiczna podstawa logiki niefregowskiej jest wyrażona w powiedzeniu Suszki: cokolwiek istnieje, jest przedmiotem, sytuacja lub funkcja" (Omyła, 2009: 78). 
Są przynajmniej dwie wersje tej koncepcji. W pierwszej z nich, warunkowo-prawdziwościowej, zdania są metajęzykowo interpretowane w postaci odpowiednich warunków prawdziwości. W drugiej, inferencyjnej, zdania języka naturalnego są bezpośrednio reprezentowane za pomocą odpowiednich formuł logicznych.

Podstawą wersji warunkowo-prawdziwościowej jest przekonanie, że właściwe założenia ontologiczne naszych wypowiedzi ujawniają się dopiero po dokonaniu ich parafraz w języku semantyki. Liczne przykłady tej wersji znajdujemy w zastosowaniach logiki filozoficznej w analizie intensjonalnych zdań języka naturalnego. Typowe analizy tego rodzaju dotyczą najczęściej dwóch rodzajów zdań: a) z funktorami modalnymi i temporalnymi typu „możliwe, że”, „konieczne, że”, „było tak, że”, „będzie tak, że” itd., w wyniku których wyróżniano zwykle kategorie: INDYWIDUUM, MOŻLIWY ŚWIAT, INTERWAŁY CZASOWE, HISTORIE oraz relacje: BYCIE ODPOWIEDNIKIEM W MOŻLIWYM ŚWIECIE, BYCIE ALTERNATYWNYM ŚWIATEM MOŻLIWYM, BYCIE WCZEŚNIEJSZYM, BYCIE RÓWNOCZESNYM;27 b) z czasownikami intencjonalnymi (w ramach semantyki sytuacyjnej 28 oraz formalnych teorii sądów i aktów mowy ${ }^{29}$ ), w wyniku których wyróżniano zwykle kategorie: OSOBA, SĄD (LOGICZNY), SYTUACJA, STAN RZECZY, oraz rozmaite relacje intencjonalne (między osobami a treściami przekonaniowymi), w szczególności: MYŚLI, WIE, CHCE, CZUJE, WIDZI, SŁYSZY, MÓWI. 30

Podejście warunkowo-prawdziwościowe ukazuje istotną rolę kategorii intensjonalnych — zwłaszcza modalnych, temporalnych, kauzalnych i przekonaniowych - w OJ.

\section{Zagadnienia związane z podejściem inferencyjnym}

Użycie logiczno-kwantyfikatorowego kryterium istnienia w wersji inferencyjnej odbywa się zasadniczo w trzech etapach: a) wskazanie przykładów typowych dla języka naturalnego wnioskowań, ocenianych intuicyjnie jako dedukcyjne, b) trafna i poprawna formalizacja tych wnioskowań, a następnie, na tej podstawie: c) wykazanie, że ich ontologicznymi zobowiązaniami są pewne ogólne tezy egzystencjalne. Stosowanie tej metody szczególnie mocno wiąże semantyczny i logiczny paradygmat ontologii.

Zasady trafnej formalizacji można zaczerpnąć (używając słów Kanta) z każdej dobrej teorii formy logicznej (TFL), na przykład — teorii pochodzącej od Gilberta Harmana (Harman, 1993):

27 Np. zdanie „Możliwe, że Jan nisko upadł” jest interpretowane następująco: zdanie „Jan nisko upadł” jest prawdziwe w pewnym możliwym świecie, alternatywnym względem świata aktualnego.

28 Zob. zwłaszcza prace Jona Barwise'a, Johna Perry'ego i Keitha Devlina z tego zakresu.

29 Zob. np. Nowak (2003).

30 Dla tego typu zdań przyjmuje się zwykle, że wyrażają one pewien stosunek intencjonalny między osobą a sądem wyrażonym w zdaniu podrzędnym (leżącym w zasięgu danego funktora intencjonalnego) lub sytuacją opisaną w tym zdaniu. Wskazana tu lista relacji jest zestawem elementarnych i uniwersalnych jednostek znaczeniowych, występujących w językach naturalnych w postaci czasowników mentalnych (plus czasownik „mówić”). Zestaw ten został podany w pracy Goddard i Wierzbicka (red.), (2002). 
Wszelkie podejście do problemu formy logicznej musi zakładać, że TFL powinna wyjaśniać oczywiste przypadki wynikania poprzez ustalenie logicznych form zdań, reguł wynikania logicznego oraz listy aksjomatów pozalogicznych. Podejście, którego będę tu bronić, zakłada także pięć dalszych zasad. [...] (1) TFL musi przypisywać formy zdaniom w taki sposób, który dopuszcza (skończoną) teorię prawdy dla danego języka.. [...](2) TFL powinna maksymalnie ograniczać nowelizacje reguł logiki. W praktyce znaczy to, że reguły wynikania logicznego powinny być jak najbliższe regułom standardowej (pierwszego rzędu) logiki kwantyfikatorów [...] (3) TFL powinna maksymalnie ograniczać aksjomaty. [...] (4) TFL powinna unikać przypisywania zdaniom danego języka zbędnych założeń ontologicznych. [...] (5) TFL musi być powiązana ze składnią. ${ }^{31}$

Jako przykłady typowych metodologicznych zagadnień związanych z omawianym podejściem, przedstawię na zakończenie dwie kwestie: a) „optymalizacji” zasad TFL oraz b) metody analizy zdań przekonaniowych.

Kwestia „optymalizacji" zasad TFL. Zagadnienie to dotyczy przede wszystkim „optymalizacji” dwóch zasad sformułowanych przez Harmana - (2), którą można by nazwać „zasadą konserwatyzmu logicznego” oraz (3), którą z kolei można by nazwać „zasadą zachowania ogólności”. Wzorcowej ilustracji dla tego zagadnienia dostarcza porównanie dwóch typów analiz zdań z przysłówkami: pochodzącego od Hansa Reichenbacha i pochodzącego od Davidsona. Rozważmy wnioskowanie.

Jan nisko upadł

$$
\text { Jan upadł }
$$

W celu wyjaśnienia intuicyjnej oceny jego formalnej poprawności najczęściej przypisuje mu się, za Davidsonem, tego rodzaju schemat:

$$
\frac{\exists x(\operatorname{CZYNNOŚĆ}(x, \mathrm{jan}) \wedge \operatorname{UPADEK}(x) \wedge \operatorname{NISKI}(x))}{\exists x(\operatorname{CZYNNOŚĆ}(x, \mathrm{jan}) \wedge \operatorname{UPADEK}(x))}
$$

(pewna czynność Jana jest upadkiem i jest „niska”; zatem pewna czynność Jana jest upadkiem). Analiza zdań tego typu, które zostały użyte w tym wnioskowaniu, wykazuje, że ich zobowiązaniem ontologicznym jest ontologiczna teza o istnieniu czynności (należących do zakresu zmienności zmiennej $x$ ). Dokładniejsza analiza podobnych zdań (m.in. z tzw. przymiotnikami niepredykatywnymi) prowadzi do wyróżnienia kategorii: AGENS, ZDARZENIE, CHWILA/OKRES, a także relacji BYCIA DZIAŁANIEM, POWODOWANIA, BYCIA WCZEŚNIEJSZYM. ${ }^{32}$

Zaletą analizy w stylu Davidsona jest utrzymanie minimalnego zbioru reguł logiki pierwszego rzędu, a więc zachowanie zasady (2) TFL. Jego wadą jest konieczność wprowadzenia w TFL, wbrew zaleceniu (3), aksjomatów pozalogicznych dotyczących predykatu CZYNNOŚĆ, ewentualnie szerszego pojęcia ZDARZENIA (jak pokazały

31 Harman (1993: 89-90).

32 Zob. np. Davidson (1995: 90-92). 
dyskusje na ten temat, złożony okazał się zwłaszcza problem określenia trafnych warunków identyczności dla zdarzeń).

Istnieje też alternatywny sposób wyjaśnienia formalnej poprawności omawianego wnioskowania. Sposób ten, pochodzący od Reichenbacha ${ }^{33}$, zakłada logikę drugiego rzędu. Jego użycie w rekonstrukcji omawianego wnioskowania daje schemat:

$\frac{\exists P(P(\text { jan }) \wedge \operatorname{UPADEK}(P) \wedge \operatorname{NISKI}(P))}{\exists P(P(\text { jan }) \wedge \operatorname{UPADEK}(P))}$

(pewna własność Jana jest jego „upadkiem” i jest „niska”; zatem pewna własność Jana jest jego „upadkiem”). Schemat ten jest pod względem formalnym podobny do poprzedniego, z tym, że zakłada kwantyfikację drugiego rzędu oraz nie wymaga wprowadzania w TFL pozalogicznych aksjomatów (a więc ma charakter reprezentacji czysto logicznej).

Formalizacja Reichenbacha jest lepsza od formalizacji Davidsona, o ile (w razie konfliktu zasad (2) i (3)) preferujemy walor ogólności związany z zasadą (3). ${ }^{34}$ W przeciwnym razie, jeśli preferowany jest walor standardowości związany z zasadą (2), formalizacja w stylu Davidsona zostanie oceniona wyżej.

Podejście pochodzące od Reichenbacha sugeruje, że logika wyższego rzędu dostarcza lepszych objaśnień ontologicznych założeń języka naturalnego niż logika elementarna. Przekonanie to można wesprzeć wieloma przykładami. Rozważmy, dajmy na to, rozumowania.

Jan jest sędzią i Piotr jest sędzią.

Bycie sędzią jest zawodem.

Jan i Piotr mają ten sam zawód.

Julia jest zawodowym muzykiem

Julia ma pewien zawód i jest muzykiem

Wyjaśnienie formalnej poprawności pierwszego z nich polega na przypisaniu mu schematu drugiego rzędu:

SĘDZIA(jan) $\wedge$ SĘDZIA(piotr) ZAWÓD(SĘDZIA)

$\exists P(P($ jan $) \wedge P($ piotr $) \wedge$ ZAWód $(P))$

33 Dokładniej, oba sposoby, również omówiony sposób „zdarzeniowy”, zostały wprowadzone już przez tego autora, zob. Reichenbach (1967: 153).

34 Warto podkreślić, że standardowa logika wyższych rzędów, w tym drugiego rzędu, zachowuje wszystkie reguły logiki pierwszego rzędu i zasadniczo zachowuje jej pojęcie modelu (w pewnym sensie jej przedmiot pozostaje ten sam). Zatem rozszerzenie logiki standardowej na logikę wyższych rzędów nie narusza zasadniczo postulatów konserwatyzmu logicznego. 
Wyjaśnienie formalnej poprawności drugiego wnioskowania polega na przypisaniu mu schematu:

$$
\frac{\exists P(P(\text { julia }) \wedge P \subset \mathrm{MUZYK} \wedge \mathrm{ZAWÓD}(P))}{\exists P(\mathrm{ZAWÓD}(P) \wedge P(\text { julia })) \wedge \mathrm{MUZYK}(\mathrm{julia})}
$$

Kwestia wyboru metody analizy zdań przekonaniowych. Na zakończenie rozważań omówimy typ wnioskowań zawierających zdania z funktorami przekonaniowymi (tj. zdania wyrażające postawy propozycjonalne lub zdania intencjonalne). Niektóre spośród tych wnioskowań wskazują na potrzebę użycia teorii, w której wartościami kwantyfikowanych zmiennych są byty propozycjonalne (uprzedmiotowione treści przekonaniowe). Oto dwa typowe przykłady.

Jan wierzy w to, że Kraków jest stolicą Polski.

Nieprawda, że Kraków jest stolicą Polski.

Jan wierzy w coś, co nie jest faktem

Jan twierdzi (to), że Kraków jest stolicą Polski.

Jan ma zawsze rację.

Kraków jest stolicą Polski.

W celu wyjaśnienia trafności naszej intuicji, że wnioskowania te są formalnie poprawne (niezależnie od faktu, że są merytorycznie niepoprawne), wprowadźmy funktor $\langle\langle. .\rangle$.$\rangle („stanu rzeczy” lub „elementarnego sądu”) tworzący symbol treści przeko-$ naniowej, mówiącej, że dana cecha przysługuje przedmiotowi lub dana relacja zachodzi między przedmiotami. W szczególności, jeśli predykat dwuargumentowy $R$ oraz nazwy jednostkowe $c, d$ są terminami prostymi, to prawdziwa jest równość:

$$
\langle\langle R, c, d\rangle\rangle=\text { to, że } R(c, d) .
$$

Predykat „jest faktem” (lub równoważnie: „jest prawdą”) oznaczmy symbolem F. Następująca równoważność objaśnia znaczenie tego symbolu:

$$
\mathrm{F}(\langle\langle R, c, d\rangle\rangle) \equiv R(c, d)
$$

Potrzebne są jeszcze pozalogiczne, dwuargumentowe predykaty przekonaniowe: Bel („wierzy”) oraz Ass („twierdzi”). Przyjmując, że zmienna s przebiega byty propozycjonalne, analiza powyższych wnioskowań wygląda następująco.

$$
\begin{gathered}
\operatorname{Bel}(a,\langle\langle R, c, d\rangle\rangle) \\
\neg R(c, d) \\
\exists s(\operatorname{Bel}(a, s) \wedge \neg \mathrm{F}(s))
\end{gathered}
$$




$$
\begin{gathered}
\operatorname{Ass}(a,\langle\langle R, c, d\rangle\rangle) \\
\forall s(\operatorname{Ass}(a, s) \rightarrow \mathrm{F}(s))
\end{gathered}
$$

$$
R(c, d)
$$

Ta analiza dostarcza dość naturalnego wyjaśnienia faktu, że intuicyjnie oceniamy rozważane wnioskowania jako formalnie poprawne: wnioski wynikają z przesłanek na mocy przyjętego postulatu znaczeniowego dla funktora F oraz podstawowych reguł logiki kwantyfikatorów (generalizacji egzystencjalnej oraz dictum de omni).

Pełne wyjaśnienie faktu konkluzywności tego rodzaju wnioskowań uzyskamy, określając dokładnie logiczną naturę bytów będących wartościami zmiennej propozycjonalnej $s$ i odpowiadając na pytanie, w jakim systemie logiki to uściślenie znajduje swój adekwatny wyraz. Na ogół przyjmuje się, że jest nim taki lub inny system logiki intensjonalnej. Okazuje się jednak, że istnieją wygodne, ekstensjonalne teorie bytów propozycjonalnych jako wartości pewnego typu zmiennych wyższego rzędu, w których tego typu wnioskowania mają adekwatne reprezentacje. Teorie takie mogą być formułowane bądź w postaci logiki trzeciego rzędu ${ }^{35}$, bądź odpowiadającej jej logicznej ontologii klas drugiego rzędu.

W takich okolicznościach pojawia się kwestia wyboru właściwej metody analizy zdań przekonaniowych w OJ — intensjonalnej bądź ekstensjonalnej.

Niezależnie od sposobu rozstrzygnięcia tej kwestii, powyższe rozważania pokazują, że takie czy inne metody formalizacji „propozycjonalnych” są użyteczne w logicznej rekonstrukcji typowych wnioskowań języka naturalnego. Nie widać też metod alternatywnych, które nie zakładałyby żadnych zobowiązań względem bytów propozycjonalnych.

W ten sposób doszliśmy do dość ważnego przykładu hipotezy z zakresu OJ: ontologiczne zobowiązania języka naturalnego obejmują nie tylko teorię klas lub własności (jako wartości zmiennych monadycznych logiki drugiego rzędu lub teorii zbiorów), ale ponadto - teorię bytów propozycjonalnych (jako wartości zmiennych propozycjonalnych).

\section{Bibliografia}

Arnould, A., P. Nicole, 1958, Logika, czyli sztuka myślenia, tł. S. Rohmanowa, Warszawa: Wydawnictwo Naukowe PWN.

Arystoteles, 1990, Dzieła wszystkie, tom 1, tł. K. Leśniak, Warszawa: Wydawnictwo Naukowe PWN.

Biłat, A., 2009, Filozoficzne podstawy logiki sytuacji, [w:] Biłat, A. (red.), 2009, 95-153.

Biłat, A. (red.) 2009, Aporie ontologii sytuacji, Lublin: Wyd. UMCS.

Bocheński, J., 1993. Logika i ontologia, [w:] Parys, J. (red.), Logika i filozofia. Wybór pism, Warszawa: Wydawnictwo Naukowe PWN.

Borkowski, L., 1991, Wprowadzenie do logiki i teorii mnogości, Lublin: TN KUL.

Chandrasekaran, B., R. Josephson, V. Benjamins, 1999, What Are Ontologies, and Why Do We Need Them?, 'IEEE Inteligent Systems' 14, 20-26.

Cocchiarella, N., 1991, Formal Ontology, [in:] H. Burkhard, B. Smith, Handbook of Metaphysics and Ontology, Munich: Philosophia Verlag, 640-641.

Cocchiarella, N., 2007, Formal ontology and conceptual realism, New York: Springer. Czeżowski, T., 1998, O metafizyce, jej kierunkach i zagadnieniach, Kęty: Wyd. Antyk.

35 Por. Biłat (2009). 
Davidson, D., 1995, Metoda prawdy w metafizyce, [w:] Szubka (red.), 1995, 79-94.

Fox, Ch., 2000, The Ontology of Language. Properties, Individuals and Discourse, Stanford: CSLI Publications.

Garbacz, P., 2009, O pocieszeniu, jakie daja stany rzeczy, [w:] Biłat, A. (red.), 2009.

Goddard, C., A. Wierzbicka (ed.), 2002, Meaning and Universal Grammar. Theory and Empirical Findings, Amsterdam/Philadelphia: John Beniamins.

Gracia, J. J. E., 1999, Metaphysics and Its Task. The Search for the Categorial Foundation of Knowledge, SUNY Press.

Harman, G., 1993, Forma logiczna, [w:] Stanosz, B. (red.), 1993, Filozofia języka, Warszawa: Fundacja Aletheia - Wyd. Spacja, 87-111.

Hintikka, J., 1983, Semantical Games and Aristotelian Categories, [in:] Hintikka, J., 1983, The Game of Language. Studies in Game-Theoretical Semantics and Its Applications, Assistant: J. Kulas, Dordrecht: D. Reidel Pub. Co., 201-229.

Kant, I., 1993, Prolegomena do wszelkiej przysztej metafizyki, która będzie mogta wystapić jako nauka, tł. B. Bornstein, Warszawa: Wydawnictwo Naukowe PWN.

Kant, I., 1997, Lectures on Metaphysics, tł. K. Ameriks, S. Naragon, Cambridge Univ. Press.

Kotarbiński, T., 1961, Elementy teorii poznania, logiki formalnej i metodologii nauk, Warszawa: Ossolineum (wyd. drugie).

Nowak, M., 2003, Formalna reprezentacja pojęcia sądu dla zastosowań w teorii aktów mowy, Łódź: Wyd. UŁ.

Omyła, M., 2009, Deskrypcje w logice niefregowskiej”, [w:] Biłat, A. (red.), 2009, 75-93.

Perzanowski, J., 1988, Ontologie i ontologiki, „Studia Filozoficzne”, nr 6-7, 87-99.

Pietruszczak, A., 2000, Metamereologia, Toruń: Uniwersytet Mikołaja Kopernika.

Quine, W. V. O., 1999, Stowo i przedmiot, tł. C. Cieśliński, Warszawa: Fundacja Aletheia.

Quine, W. V. O., 2000, O tym, co istnieje, [w:] tenże, Z punktu widzenia logiki. Eseje logiczno-filozoficzne, tł. B. Stanosz, Warszawa: Fundacja Aletheia, 29-47.

Reichenbach, H., 1967, Elementy logiki formalnej (fragmenty), [w:] Pelc, J. (red.), Logika i jezzy. Studia z semiotyki logicznej, Warszawa: Wydawnictwo Naukowe PWN, 3-222.

Sarbo, J. J., J. Farkas, 2001, A Peircean Ontology of Language, Lecture Notes In Computer Science, Vol. 2120 (Proceedings of the 9th International Conference on Conceptual Structures: Broadening the Base), 1-14.

Smith, B., 1987, Husserl, Language, and the Ontology of the Act, [in:] Buzzetti D., M. Ferriani (ed.), Speculative Grammar, Universal Grammar, and Philosophical Analysis of Language, Amsterdam, John Benjamins, 205-227.

Smith, B., 2003, Ontology, [in:] Floridi L. (ed.), Blackwell Guide to the Philosophy of Computing and Information, Oxford: Blackwell, 155-166.

Strawson, P., 1960, Metaphysics, [in:] Urmson J. O. (ed.), The Concise Encyclopedia of Western Philosophy, London: Hutchinson, 259-264.

Strawson, P., 1980, Indywidua. Próba metafizyki opisowej, tł. B. Chwedeńczuk, Warszawa: Instytut Wyd. PAX.

Strawson, P., 1994, Analiza i metafizyka. Wstęp do filozofii, tł. A. Grobler, Kraków: Wyd. Znak.

Szubka, T., 1995, Metafizyka analityczna P.F. Strawsona, Lublin: RW KUL.

Szubka, T. (red.), 1995, Metafizyka w filozofii analitycznej, Lublin: Tow. Naukowe KUL.

Trendelenburg, A., 1846, Geschichte der Kategorienlehre, Berlin: Verlag von G. Bethe.

Trypuz, R., P. Garbacz, 2007, Bity $i$ byty. O pewnym mato znanym zastosowaniu ontologii, „Filozofia Nauki”.

Wierzbicka, A., 2006, Semantyka. Jednostki elementarne i uniwersalne, Lublin: Wyd. Naukowe UMCS (przekład z oryginału: A. Wierzbicka, 1966, Semantics. Primes and Universals, Oxford Univ. Press).

Wojtysiak, J., 2002, Kategorie. Przeglad stanowisk i zagadnień, [w:] Studia metafilozoficzne II, Lublin: TN KUL, 93-186. 